\title{
ON THE CHANGE IN THE COMPOSITION OF BUTTER BY LONG KEEPING.
}

\author{
By A. H. Allenn and C. G. Moor.
}

Is the discussion on a paper recently read before this Society by Mr. Richmond, a question arose as to the extent to which butter decomposed by long keeping. As a contribution to the existing knowledge on this obscure question, it occurred to us that it would be interesting to analyze some samples of butter which had been in our possession since November, 1888 . These samples were closely packed in tins, and had remained intact since the packages were sealed in Denmark more than five 
years ago. The butter-fat obtained by rendering the fresh butter was analyzed at the time very carefully, and the results were published in a paper by one of us in The Analyst for January, 1889.

Three tins of the " $\mathrm{B}$ " butter and one of the " $\mathrm{O}$ " butter still existed, and it is the fat from these which we have recently submitted to analysis. The samples of " $B$ " were badly decomposed, but the one remaining portion of " $\mathrm{O}$ " showed little or no sign of decomposition. It will be observed that the change undergone by this butter, as indicated by the results of the analysis, is comparatively trifling, whereas in the samples of " $B$," in which the decomposition was much more profound, the changes are extreme. Further, the changes in portions " B 1," " B 2," and " B 3," which have been kept side by side since 1888 , have not proceeded with the same rapidity.

We are pleased to acknowledge the zealous assistance of Mr. G. S. A. Caines, who made the recent analyses given in the following table:

\begin{tabular}{|c|c|c|c|c|c|c|c|c|}
\hline & \multicolumn{5}{|c|}{ Butter marked " B." } & \multicolumn{3}{|c|}{ Butter marked " 0. " } \\
\hline & \multicolumn{2}{|c|}{$\begin{array}{c}\text { Rendered and } \\
\text { Analyzed } \\
\text { November, } 1888 .\end{array}$} & \multicolumn{3}{|c|}{$\begin{array}{c}\text { Rendered and } \\
\text { Analyzed March, } \\
1894 .\end{array}$} & $\begin{array}{l}\text { Ren- } \\
\text { dered and } \\
\text { Analyzed } \\
\text { Nov., }\end{array}$ & \begin{tabular}{|} 
Ren- \\
deredand \\
Analyzed \\
Nov.,
\end{tabular} & $\begin{array}{c}\text { Ren- } \\
\text { dered and } \\
\text { Analyzed } \\
\text { March, }\end{array}$ \\
\hline & $\begin{array}{l}\text { Copen- } \\
\text { hagen. }\end{array}$ & London. & $\begin{array}{l}\text { London. } \\
1\end{array}$ & $\begin{array}{l}\text { London. } \\
\quad 2\end{array}$ & $\begin{array}{c}\text { London. } \\
3\end{array}$ & $\begin{array}{l}\text { Copen- } \\
\text { hagen. }\end{array}$ & London. & London. \\
\hline $\mid \begin{array}{ccc}\text { Specific } & \text { gravity } & \text { at } \\
100^{\circ} \mathrm{C} . & \ldots & \ldots \\
\text { C.C. of } \frac{\mathrm{N}}{10} \text { alkali } & \text { re- } \\
\text { quired for } 5 \text { grammes } \\
\text { by Reichert-Wollny }\end{array}$ & 8639 & $\cdot 8640$ & $\cdot 8634$ & ·8696 & $\cdot 8730$ & $· 8641$ & $\cdot 8641$ & \\
\hline $\begin{array}{cc}\text { process } \\
\text { Percentage of } \mathrm{KHO}\end{array}$ & $22 \cdot 63$ & $22 \cdot 39$ & $14 \cdot 43$ & $12 \cdot 02$ & $12 \cdot 02$ & $24 \cdot 39$ & $24 \cdot 70$ & $22 \cdot 48$ \\
\hline $\begin{array}{lll}\text { required for } & \text { saponi- } \\
\text { fication } & \ldots & \ldots \\
= & \text { Sannification }\end{array}$ & $22 \cdot 27$ & $22 \cdot 05$ & $21 \cdot 99$ & $22 \cdot 55$ & $22 \cdot 88$ & $22 \cdot 15$ & $22 \cdot 03$ & $23 \cdot 33$ \\
\hline $\begin{array}{ccc}=\text { saponincation } & \text { equi- } \\
\text { valent } & \ldots & \ldots\end{array}$ & $251 \cdot 9$ & $254 \cdot 4$ & $255 \cdot 1$ & $248 \cdot 7$ & $245 \cdot 2$ & $253 \cdot 3$ & $254 \cdot 6$ & \\
\hline $\begin{array}{ccc}\text { Soluble fatty acids, per } \\
\text { cent. } & \ldots & \ldots\end{array}$ & - & $\left\{\begin{array}{l}4 \cdot 37 \\
4 \cdot 50 \\
4 \cdot 45\end{array} \mid\right.$ & $3 \cdot 82$ & $5 \cdot 66$ & $5 \cdot 80$ & - & $\left\{\begin{array}{l}4 \cdot 60 \\
4 \cdot 66 \\
4 \cdot 77\end{array}\right.$ & $5 \cdot 89$ \\
\hline $\mid \begin{array}{cr}\text { Insoluble fatty } & \text { acids, } \\
\text { per cent. } & \ldots\end{array}$ & 一 & $\left\{\begin{array}{l}90 \cdot 24 \\
90 \cdot 62\end{array} \mid\right.$ & $90 \cdot 73$ & $90 \cdot 70$ & $90 \cdot 00$ & 一 & $\left\{\begin{array}{l}89 \cdot 90 \\
90 \cdot 30\end{array}\right.$ & $85 \cdot 78$ \\
\hline $\left.\begin{array}{c}\text { Iodine absorption, } \\
\text { per cent. } \quad . .\end{array}\right\}$ & $\begin{array}{l}\text { Not } \\
\text { done }\end{array}$ & $\begin{array}{c}\text { Not } \\
\text { done }\end{array}$ & $30 \cdot 01$ & $27 \cdot 17$ & $25 \cdot 08$ & $\begin{array}{l}\text { Not } \\
\text { done }\end{array}$ & $\begin{array}{l}\text { Not } \\
\text { done }\end{array}$ & $25 \cdot 57$ \\
\hline $\begin{array}{c}\text { Condition of the butter } \\
\text { when rend ered }\end{array}$ & Fresh & Fresh & $\begin{array}{c}\text { De- } \\
\text { com- } \\
\text { posed }\end{array}$ & $\begin{array}{c}\text { De- } \\
\text { com- } \\
\text { posed }\end{array}$ & $\begin{array}{l}\text { De- } \\
\text { com- } \\
\text { posed }\end{array}$ & Fresh & Fresh & $\begin{array}{c}\text { Showed } \\
\text { no signs } \\
\text { of decom- } \\
\text { position. }\end{array}$ \\
\hline
\end{tabular}

\section{Discussion.}

Mr. Allen said that the figures were no doubt surprising, and he could not see his way to offer any definite explanation of them. It would be noticed how, in the 
samples of "B" recently analyzed, the Reichert figure had fallen from 22 to 14 , and even to 12 , whereas in the sample marked " $O$ " it had fallen from $24 \cdot 7$ to $22 \frac{1}{2}$. On the other hand, if the figures for the soluble acids were examined, it would be found that, out of three tins of the same butter kept side by side, only one had undergone decrease. The insoluble acids had not very greatly altered. The iodine absorption also varied. The figures seemed to indicate that it was impossible to tell from such data-without going into the differentiation of the nature of the volatile acids - what change had occurred; nor could it be said that, because one sample of butter had altered in a certain manner, another was likely to alter in the same way. The two samples " $B$ " and " $O$ " had behaved in a different manner, though they bad been kept under the same conditions as to exposure, absence of light, etc. It was not very often that an opportunity presented itself of making analysis of butter after so long a period of time.

Dr. Sykes thought it possible that the differences observed on long keeping might be explained by the differing nature of the bacteria which had obtained access to the samples. So far as he knew, the effects of bacterial action upon fats had yet to be worked out.

Mr. Richmond said that, in the butters which had decomposed, the disturbance between the normal ratios of the figures determined was very marked. It would be noticed in the three samples "B" that the Reichert-Wollny figure had gone down very considerably. The figure for the soluble fatty acids had, in the first case, gone down a very little, but by no means in proportion to the volatile acids, and in the otber two it had gone up. When butter decomposed a hydrolysis undoubtedly took place, and the liberated fatty acids would be partly dissolved in the water of the butter. The same order of things was apparent in the case of the butter " $O$ " as in "B," although the Reichert-Wollny figure had not gone down to such a marked extent. The figure for the soluble fatty acids had, however, gone up. About two years ago he had occasion to make determinations on about fifteen or sixteen samples, and estimating the Reichert-Wollny figure and the soluble acids, he found that the relations between the two were fairly constant. A mean ratio of 86.5 per cent. was found in the distillate, and this agreed fairly with the ratios originally found by $\mathrm{Mr}$. Allen. In the examples shown on the board it was very easy to see that the ratio of the quantity distilled over in the Reichert-Wollny process to the total soluble acid had gone down to something like 50 per cent. in the butter marked " B 1," and about 70 per cent. in the butters marked " B 2 and B 3." There was also a change in the iodine absorption. When the butters were analyzed in 1888 iodine absorptions were not determined. Working in Mr. Hehner's laboratory, he had also, through the kindness of Mr. Allen, examined these butters; he believed his Reichert-Wollny figure was almost the same; as far as his recollection went, the iodine absorption was close upon 40 per cent. ; so taking this as the original figure, there had evidently been a large diminution. As regarded the increase in the soluble fatty acids, it was evident that they were not distilled over in the Reichert-Wollny process, and, therefore, that they could not be the same kind of acid as that distilled, that is to say, the lower fatty acids of the acetic acid series. Some years ago a series of papers was 
published by Hazura, who studied the action of alkaline permanganate, and he obtained by oxidation hydroxyacids from the unsaturated fatty acids of various kinds. Some of these acids were soluble in water, and he (Mr. Richmond) thought it was highly probable that old butters would contain considerable percentages of hydroxyacids produced by oxidation. Hydroxyacids had a high density, and the increase of density again indicated the presence of this class of compound. He had in his possession a sample which had been sealed up by Dr. Vieth, and which had been kept for a considerable time; the air had been excluded from it, it had been kept in the dark, and it showed no signs of decomposition. It would seem that if the butter was excluded from the air it kept much better, and that oxidation was an important factor. This was one of the facts which led him to think that the soluble acids might be hydroxyacids soluble in water. From a study of the results of fractional distillation of butter acids he had evidence of a soluble acid of less volatility than butyric, and it was not impossible that this was a hydroxyacid (e.g., lactic). He would like to mention that it was extremely useful to determine the rise of temperature with strong sulphuric acid. He had found in the case of olive-oil that the rise had a quantitative meaning, and that a certain amount of rise could be assigned to acids of each series. It would be extremely interesting to determine it if the authors had a sufficient quantity of the butters left. He (Mr. Richmond) had given up the use of 50 grammes of the oil or fat for 25 grammes oil and 5 c.c. of acid, and found the results more accurate. In fact, he found that, with the apparatus which he used, he could get within 1 or 2 tenths of a degree centigrade. Messrs. Allen and Moor's figures were of great interest, and there seemed considerable hope that the analysis of decomposed butter would afford information as to its original composition. Glycerol determinations might be of use, as probably this would be attacked.

Mr. Moor stated that in the case of the "B" butters the samples had attacked the tinned iron box, and were quite brown in colour; whereas this was not the case with the "O" butter, which did not show any appearance of decomposition, or possess the strong smell of bad cheese which characterized the "B" samples.

In the absence of the author, the following paper was read by Dr. Dyer: 